\title{
Erysiphe quercicola, a powdery mildew fungus on Khasi mandarin in North East India
}

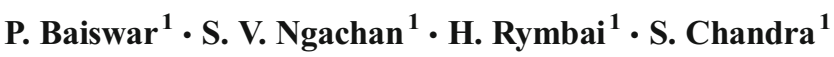

Received: 8 June 2015 / Accepted: 6 October 2015 / Published online: 14 October 2015

(C) Australasian Plant Pathology Society Inc. 2015

\begin{abstract}
Powdery mildew on Khasi mandarin (Citrus reticulata) is considered as one of the factors responsible for citrus decline in this region. Molecular identification was done for powdery mildew pathogen (anamorph) on Citrus reticulata based on nrDNA ITS region (ITS 1-5.8s and ITS2). Maximum likelihood analysis clustered the sequences from this study with Erysiphe quercicola.
\end{abstract}

\section{Keywords Citrus reticulata $\cdot$ Erysiphe quercicola $\cdot$ Erysiphe alphitoides $\cdot$ ITS}

North East India has very rich diversity of Citrus spp. (Patel et al. 2008). Khasi mandarin (Citrus reticulata) is the main species cultivated in this region. However, in the past few years, citrus decline has become a major problem reducing the yield of previously highly productive plants. Many abiotic and biotic factors are considered responsible for the decline and powdery mildew is among one of the major causes severely affecting new flushes and seedlings (Singh 2006; Sharma et al. 2001).

In the absence of chasmothecia and reliable anamorphic characters, nuclear rDNA region can be used successfully to link a species anamorph to its corresponding teleomorph and to investigate phylogenetic relationships between different powdery mildew species (Braun and Takamatsu 2000;

\section{P. Baiswar}

pbaiswar@yahoo.com

1 ICAR Research Complex for NEH Region, Umiam, Meghalaya 793103, India
Cunnington 2002; Cunnington et al. 2003; Takamatsu 2004; Takamatsu et al. 2006).

Khasi mandarin leaves with abundant greyish-white powdery mildew colonies (Fig. 1) were collected for morphological analysis using scanning electron microscopy (SEM) and molecular identification. The voucher specimen was deposited at the Agharkar Research Institute Herbarium, Pune, India (AMH- 9665).

Scanning electron microscopy (JEOL JSM 6360, JEOL, Tokyo, Japan) was conducted on pre-prepared specimens. Powdery mildew colonies were selected using a dissecting microscope and placed on double-sided cellotape then sputter-coated with gold under vacuum using Fine Coat Ion Sputter JFC-1100. Gold-coated samples were then placed on aluminium stubs for SEM. Conidia were ellipsoid- cylindrical (LM) and had longitudinal 'angular' wrinkling patterns (using SEM) on the conidial surface and lobed appressoria on hyphae were observed which are considered typical for Erysiphe sp. (Pseudoidium anamorph) (Figs. 2 \& 3) (Braun and Cook 2011).

The genomic DNA of isolates Pmcr-01 and Pmcr-02 was extracted using the Qiagen Stool Kit. Nested PCR was performed using ITS 5-4 then ITS 1- PM 6 combinations. The PCR was performed in a total volume of $50 \mu \mathrm{l}$ with the following reagents; ready to use Thermo Scientific DreamTaq PCR Master Mix $(\times 2)$ (Thermo Fisher Scientific)- $25 \mu$ l containing DNA polymerase, PCR buffer, $\mathrm{MgCl}_{2}$ and dNTPs, $0.4 \mu \mathrm{l}$ of each primer and $\sim 10 \mathrm{ng}$ of template DNA. Cycling conditions were initial denaturation $5 \mathrm{~min}\left(94^{\circ} \mathrm{C}\right)$, denaturation $30 \mathrm{~s}\left(94{ }^{\circ} \mathrm{C}\right)$, annealing $40 \mathrm{~s}\left(52-50{ }^{\circ} \mathrm{C}\right.$, stepdown approach $-1{ }^{\circ} \mathrm{C}$ in each cycle), extension $50 \mathrm{~s}\left(72{ }^{\circ} \mathrm{C}\right)$ and final extension $10 \mathrm{~min}\left(72^{\circ} \mathrm{C}\right)$. These PCR conditions were 


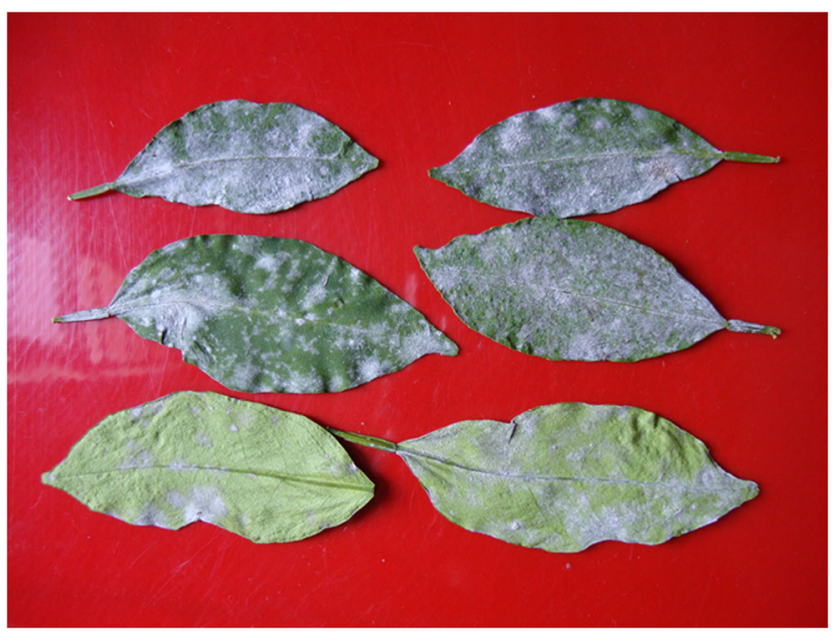

Fig. 1 Powdery mildew symptoms on the leaves of Khasi mandarin

according to Takamatsu and Kano (2001) with minor modifications. Sequencing was done using primers ITS 1 and PM 6.

Consensus sequences were generated, deposited in GenBank (KP797974 and KR131403) and compared with those of reference strains in the GenBank database (Limkaisang et al. 2006; Holford et al. 2010; Takamatsu et al. 2007). Alignment was done using Muscle implemented in MEGA 6.0 (Tamura et al. 2013). Evolutionary model was inferred using jModeltest (Posada 2008). Phylogenetic analysis was done using the Maximum likelihood method with Tamura-3- parameter model. Clade stability was assessed by 1000 bootstrap replicates with random sequence addition. A discrete Gamma distribution was used to model evolutionary rate differences among sites. Tree optimisation was done using an extensive subtree pruning and regrafting method (SPR-5).

The ITS sequences (KP797974 and KR131403) of powdery mildew isolates from Khasi mandarin were $99 \%$ similar to E. quercicola (AB237791, $\mathrm{AB} 237792, \mathrm{AB} 237793$ ) and

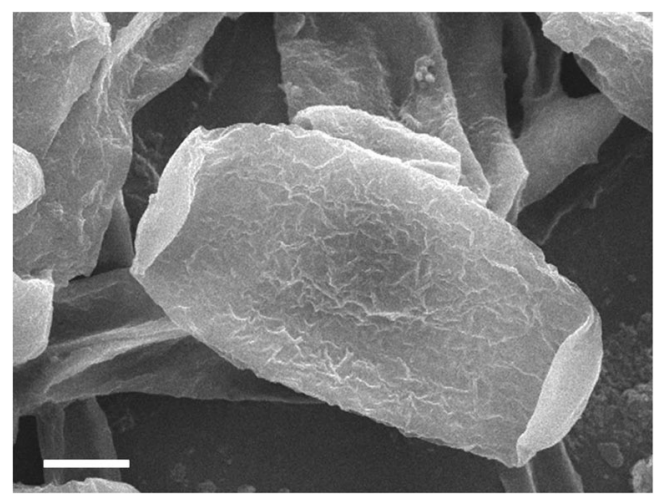

Fig. 2 Longitudinal 'angular' wrinkling pattern on the conidium of Erysiphe quercicola $($ Bar $=5 \mu \mathrm{m})$

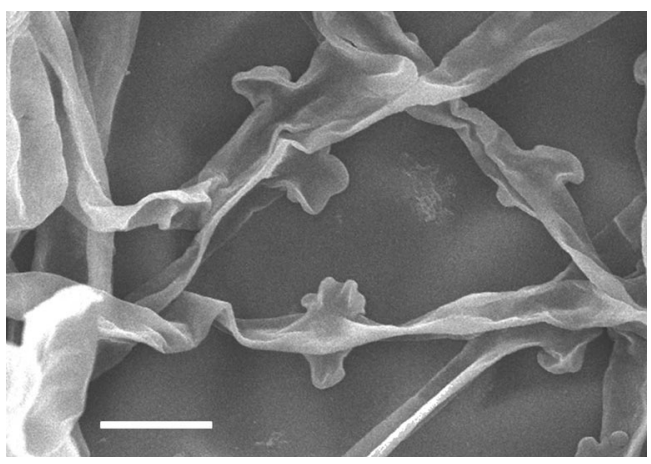

Fig. 3 Appressoria on hyphae of the anamorph of Erysiphe quercicola $($ Bar $=10 \mu \mathrm{m})$

Oidium citri (HM164136) sequences in nBlast searches. The maximum likelihood analysis clustered KP797974 and KR131403 with the rest of E. quercicola reference sequences with a bootstrap value of $99 \%$ (Fig. 4). The tree was rooted with the sequence of E. abbreviata (AB271785). Based on these results, it is clear that the anamorph of the powdery mildew pathogen on Citrus reticulata belongs to E. quercicola.

Two species that cause powdery mildew are recorded on Citrus spp., Fibroidium tingitaninum (= Oidium tingitaninum) and Pseudoidium anacardi (= Oidium citri), with the last species having non-catenate conidia (Braun and Cook 2011). The causal organism of powdery mildew on Khasi mandarin has previously been identified as Oidium tingitaninum (=Acrosporium tingitaninum) in some reports from different parts of North East India (Gupta and Srivastava 1994). The anamorph of E. quercicola also has non-catenate conidia.

Takamatsu et al. (2007) named the fungus on Quercus phillyraeoides, as Erysiphe quercicola. This fungus was distributed in warmer regions in southern Japan, was genetically separated from E. alphitoides sensu stricto, and had chasmothecia with appendages shorter than the chasmothecial diameter (in case of $E$. alphitoides appendages are $0.75-2$ times as long as the chasmothecial dia.) (Takamatsu et al. 2007). Erysiphe quercicola is able to infect other oak species and shows a high level of genetic similarity to anamorphs of powdery mildew species that colonise hosts such as Citrus spp., Anacardium occidentale (cashew), Mangifera indica (mango) and Acacia spp. from tropical and subtropical regions of Asia, Africa and South America (Takamatsu et al. 2007). In the absence of chasmothecia it is very difficult to distinguish E. quercicola from E. alphitoides as the anamorph characters are not clearly distinguishable (Takamatsu et al. 2007).

This appears to be the first correct record of powdery mildew pathogen on C. reticulata from North East India based on molecular identification. The present findings are important 
Fig. 4 Phylogenetic tree inferred using the maximum likelihood method and bootstrap values are depicted above the branches. Scale bar represents number of substitutions per site

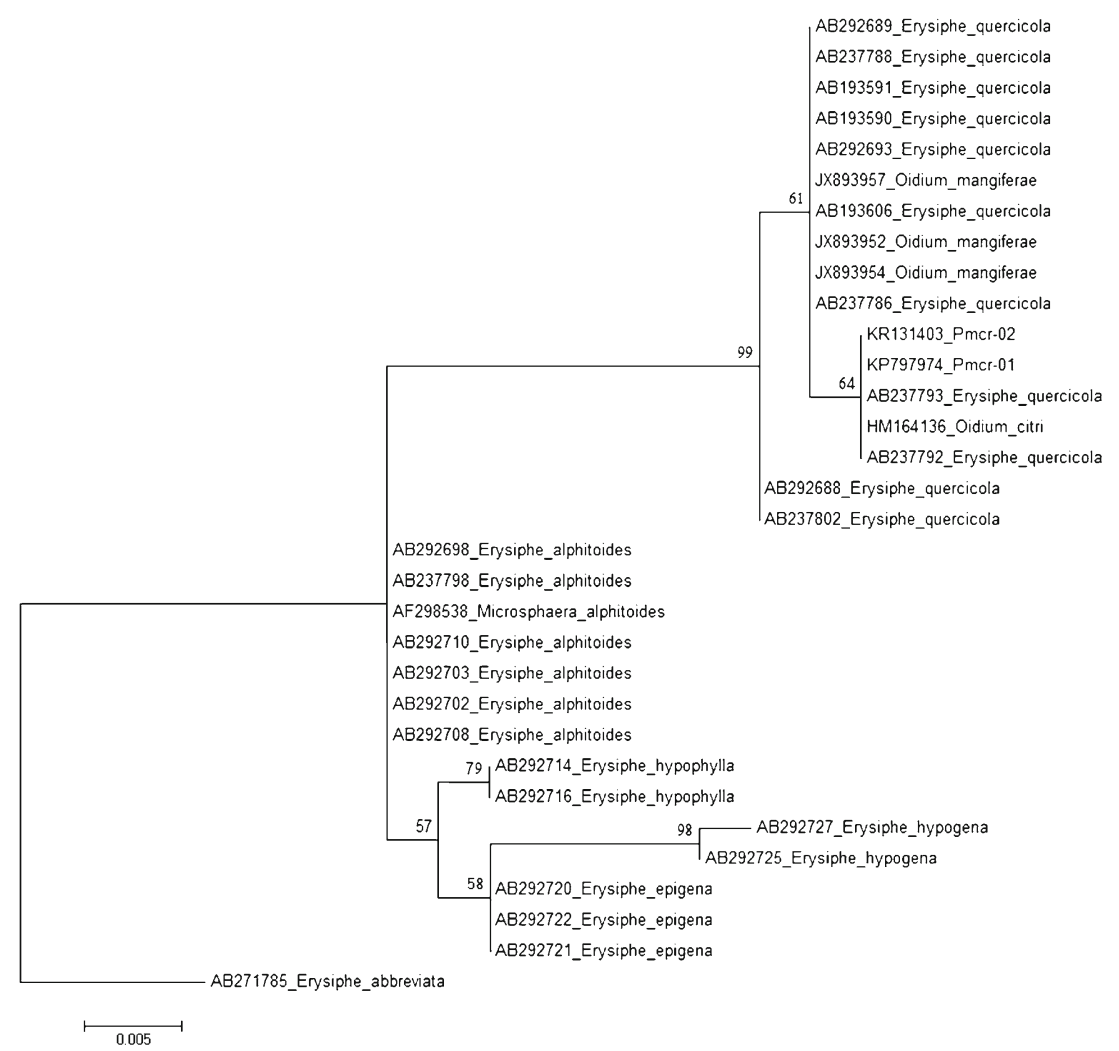

since Khasi mandarin is the main crop grown by farmers in the North East and powdery mildew is a devastating disease causing huge losses especially on new growth and in seedling stage.

Acknowledgments This work was done under the Institute project (IXX05432). Authors would like to thank Dr. RTA Cook for his kind suggestions, Animal Production Division of our Institute for providing facilities for molecular work and the Head, SAIF, Dr. Sudeep Dey (Scientific Officer), Dr. R. Charkraborty, N. K. Rynjah for scanning electron microscopy at North-eastern Hill University, Shillong, Meghalaya, India. Authors wish to dedicate this article to Late Dr. R Basumatary and Late Mr. RC Tamuli.

\section{Compliance with ethical standards}

Conflict of interest The authors declare that they have no conflict of interest.

\section{References}

Braun U, Cook RTA (2011) Taxonomic manual of the Erysiphales (Powdery mildews). CBS Biodiversity Series No. 11, Utrecht, The Netherlands
Braun U, Takamatsu S (2000) Phylogeny of Erysiphe, Michosphaera, Uncinula (Erysipheae) and Cystotheca, Podosphaera, Sphaerotheca (Cystotheceae) inferred from rDNA ITS sequences - some taxonomic consequences. Schlechtendalia 4:1-33

Cunnington JH (2002) Molecular identification of anamorphic powdery mildew fungi in Australia. PhD thesis. RMIT University, Bundoora, Australia

Cunnington JH, Takamatsu S, Lawrie AC, Pascoe I (2003) Molecular identification of anamorphic powdery mildews (Erysiphales). Australas Plant Pathol 32:421-428

Gupta DK, Srivastava LS (1994) Powdery mildew flora of Sikkim. Indian J Hill Farming 7:207-209

Holford P, Donovan NJ, Thinlay, Kabanoff E, Wildman O, Hardy S, Beattie GAC, Namgay O, Dorjee, Wangdi P (2010) First report of Oidium citri in Bhutan. Australas Plant Dis Notes 5:55-57

Limkaisang S, Cunnington JH, Wui LK, Salleh B, Sato Y, Divarangkoon R, Fangfuk W, To-Anun C, Takamatsu S (2006) Molecular phylogenetic analyses reveal a close relationship between powdery mildew fungi on some tropical trees and Erysiphe alphitoides, an oak powdery mildew. Mycoscience 47:327-335

Patel RK, Singh A, Deka BC, Ngachan SV (2008) Handbook of fruit production (North Eastern hill region). ICAR Research Complex for NEH Region, Umiam, Meghalaya

Posada D (2008) jModelTest: phylogenetic model averaging available from http://darwin.uvigo.es/software/jmodeltest.html

Sharma YP, Prasad MS, Prasad MSL, Chandra S, Singh AK, Kumar S (2001) Crop diseases and their management. In: Verma ND, Bhatt $\mathrm{BP}$ (eds) Steps towards modernization of agriculture in NEH region. Venus Printers and Publishers, New Delhi, pp. 175-192 
Singh S (2006) Citrus industry of India- constraints and strategies. In: Shivanker VJ (ed) Proceedings of National Symposium on Citriculture- a road map. pp 1-21. Meghalaya, India

Takamatsu S (2004) Phylogeny and evolution of the powdery mildew fungi (Erysiphales, Ascomycota) inferred from nuclear ribosomal DNA sequences. Mycoscience 45:147-157

Takamatsu S, Kano Y (2001) PCR primers useful for nucleotide sequencing of rDNA of the powdery mildew fungi. Mycoscience 42:135139
Takamatsu S, Matsuda S, Niinomi S, Havrylenko M (2006) Molecular phylogeny supports a Northern Hemisphere origin of Golovinomyces (Ascomycota: Erysiphales). Mycol Res 110:1093-1101

Takamatsu S, Braun U, Limkaisang S, Kom-un S, Sato Y, Cunnington JH (2007) Phylogeny and taxonomy of the oak powdery mildew Erysiphe alphitoides sensu lato. Mycol Res 111:809-826

Tamura K, Stecher G, Peterson D, Filipski A, Kumar S (2013) MEGA6: molecular evolutionary genetics analysis version 6.0. Mol Biol Evol: 30:2725-2729 